\title{
Effect of sewage sludge on nitrogen availability in peat
}

\author{
J. A. Diez ${ }^{1}$, A. Polo ${ }^{1}$, and F. Guerrero ${ }^{2}$ \\ ${ }^{1}$ Centro de Ciencias Mediambientales (CSIC), E-28006 Madrid, Spain \\ ${ }^{2}$ Escuela Técnica Superior de Ingenieros Agrónomos, E-28049 Madrid, Spain
}

Received November 28, 1991

Summary. We studied the effect of incubating peat with lime and sewage sludge in small proportions on biological activity and $\mathrm{N}$ mineralization. The peat response was dependent on $\mathrm{pH}$ and, in acid peats, on mineralization capacity. In acid peats, the addition of sewage sludge inhibited biological activity. Only the most eutrophic peats (Herbosa) responded with accelerated mineralization. The addition of lime to acid peats favoured organic matter mineralization, shown by a greater $\mathrm{CO}_{2}$ release. The best results were obtained by adding lime and sewage sludge together. In saline peats, the best $\mathrm{N}$ levels were obtained without incubation.

Key words: Sewage sludge - Peat $-\mathrm{N}$ availability Electro-ultrafiltration - Liming

Peat is used in agriculture as an organic amendment to soil (Dyal 1960; Lamb 1969; Gallagher 1975; Puustjarvi 1975) because it contains large amounts of organic $C$ in a very stable form. However, the biological activity of peat is very low and other materials must be added to promote the degradation of the peat organic matter. Urban waste seems a suitable material because it contains microorganisms that can increase the mineralization of organic $\mathrm{C}$, causing a profound physicochemical transformation in the peat (Guerrero et al. 1987).

Applications of peat improve the physical properties of soil (Boelter 1969; Bunt 1974; Puustjarvi 1974). The most important nutrient in peat is $\mathrm{N}$, which may comprise as much as $2 \%$ of the peat (Guerrero et al. 1987). The content of other elements is generally low. Although organic matter mineralization is slow, the transformation of $\mathrm{N}$ into different forms does occur. Diez et al. (1990) showed that peats have low levels of microbial activity, a low capacity for mobilizing $\mathrm{N}$, and a high capacity for immobilizing $\mathrm{N}$ added to the soil as a fertilizer.
Since little information has been obtained with conventional methods of studying $\mathrm{N}$ dynamics in peat, we have obtained positive results previously (Diez et al. 1990), we used the electro-ultrafiltration technique to characterize different $\mathrm{N}$ fractions (organic $\mathrm{N}, \mathrm{NO}_{3}^{-}$, $\mathrm{NH}_{4}^{+}$) in a soil extract (Nemeth et al. 1979; Wiklicky and Nemeth 1991).

The aim of this work was to improve the potential of the peats for use as fertilizers, by reactivating mineralization through the addition of sewage sludge in low proportions, and to evaluate the effects of the sludge on the changes shown in $\mathrm{N}$ dynamics by electro-ultrafiltration.

\section{Materials and methods}

We used samples from three Spanish peat bogs (Llano de Roñanzas, Asturias; Herbosa, Burgos; Torreblanca, Alicante), representing the whole soil profile. The chemical properties are reported in Table 1. Sampling sites and other properties of the first two peats have already been described by Guerrero and Polo (1988 a, b).

The sewage sludge was from the Valdebebas (Madrid) treatment plant and has been characterized by Diaz-Burgos and Polo (1991). The contents of some elements are given in Table 2.

Electrical conductivity and $\mathrm{pH}$ were determined in a $1: 5$ soil : water mixture; total $C$ was determined with a Carmograph-12 analyser and total $\mathrm{N}$ by the Kjeldahl method, with determination of $\mathrm{NH}_{4}^{+}$as produced by the Technicon AAII Autoanalyser. Cation exchange capacity was assessed as reported by Mehlich (1948) and lignin and cellulose were determined according to Van Soest and Malcolm (1968).

Total element concentrations were measured by atomic absorption spectrophotometry after extraction (soil solution ratio, $1: 50$ ) with a nitric-perchloric (ratio 1:50) acid solution.

Incubation was carried out for 35 days as reported by Polo et al. (1983); four treatments (four replicates, each using $45 \mathrm{~g}$ peat) were carried out, one unincubated peat treatment and four incubated peat treatments, including a control; liming to $\mathrm{pH} 7$ with calcium hydroxide; addition of sewage sludge $(0.3 \%)$; and liming + sewage sludge $(0.3 \%)$.

The $\mathrm{CO}_{2}$ released was collected in $50 \mathrm{ml} 0.2 \mathrm{~N} \mathrm{NaOH}$ in order to determine daily and accumulated mineralization curves. The total mineralization coefficient (CMT) was defined by the expression: 
Table 1. Chemical properties of peats

\begin{tabular}{|c|c|c|c|c|c|c|c|c|}
\hline Sample & $\begin{array}{l}\mathrm{EC} \mathrm{pH} \\
\qquad\left(\mathrm{H}_{2} \mathrm{O}\right)\end{array}$ & $\begin{array}{l}\text { Ash } \\
(\%)\end{array}$ & $\begin{array}{l}C \\
(\%)\end{array}$ & $C: N$ & CEC & Type & $\begin{array}{l}\text { Lignin } \\
(\%)\end{array}$ & $\begin{array}{l}\text { Cellulose } \\
(\%)\end{array}$ \\
\hline LL & 603.5 & 5.8 & 44.6 & 29.7 & 132 & Hemic & 49.1 & 23.2 \\
\hline $\mathrm{H}$ & 5203.6 & 9.3 & 45.1 & 37.5 & 113 & Hemic & 35.3 & 32.1 \\
\hline $\mathrm{T}$ & 101207.1 & 42.9 & 27.1 & 19.3 & 132 & Sapric & 32.3 & 22.9 \\
\hline Sludge & 67006.9 & 62.3 & 21.2 & 10.0 & 58 & & & \\
\hline
\end{tabular}

CEC, Cation exchange capacity (meq $100 \mathrm{~g}^{-1}$ ); EC, electrical conductivity at $25^{\circ} \mathrm{C}\left(\mu \mathrm{S} \mathrm{cm}^{-1}\right) ; \mathrm{LL}$, Llano de Roñanzas; $\mathrm{H}$, Herbosa; $\mathrm{T}$, Torreblanca

Two $\mathrm{N}$ fractions were obtained by electro-ultrafiltration (Nemeth 1979), one after $30 \mathrm{~min}$ at $20^{\circ} \mathrm{C}(200 \mathrm{~V}, 15 \mathrm{~mA}$ maximum) and the other after $5 \mathrm{~min}$ at $80^{\circ} \mathrm{C}(400 \mathrm{~V}, 150 \mathrm{~mA}$ maximum).

The soil samples were air-dried, crushed, and passed through a 1-mm sieve; $5 \mathrm{~g}$ was taken from each sample for extraction by electroultrafiltration. The anode and cathode extracts relating to each fraction were mixed. The data reported in Figs. 1, 2, and 3 are the sum of both fractions.

The total $\mathrm{N}$ in each electro-ultrafiltration fraction was determined with an autoanalyser by ultraviolet irradiation and subsequent oxidation with potassium persulphate in a strongly alkaline medium, in order to transform the $\mathrm{N}$ compounds into $\mathrm{NO}_{3}^{-}$(Diez 1988) which was determined $\mathrm{Nl}$ naphthylethylenediamine (Technicon 1966). $\mathrm{NO}_{3}^{-}$was determined before and after oxidation by a Technicon AAII Autoanalyser. The $\mathrm{NH}_{4}^{+}$in the extracts was determined by the nitroprussite method (Dabin 1967) by the same Autoanalyser. The organic $\mathrm{N}$ content (low molecular weight nitrogenous compounds), representing the organic fraction that is mineralized in the short term, was determined by the difference between total $\mathrm{N}$ and $\mathrm{NO}_{3}^{-}+\mathrm{NH}_{4}^{+}$.

\section{Results and discussion}

The values obtained for the electro-ultrafittration $\mathrm{N}$ fractions were the final result of a series of transformations which took place during incubation, e.g., volatilization of $\mathrm{NH}_{3}^{-}$or immobilization of $\mathrm{N}$ by microorganisms.

The addition of sewage sludge + lime had different effects on peat decomposition, depending on the type of peat, as shown by Figs. $1-3$.

The addition of sewage sludge to the Llano de Roñanzas peat (Fig. 1) had no significant effects on the electro-ultrafiltration EUF-N values despite the high level of total $\mathrm{N}\left(1500 \mathrm{mg} \mathrm{N} 100 \mathrm{~g}^{-1}\right)$ in the peat. This probably reflected the moderately high $\mathrm{C}: \mathrm{N}$ ratio $(29.7)$ and a mid-low cellulose content (Table 2 ). In addition, this peat is low in nutrients, and therefore its mineralization capacity is low (Table 3); consequently, different values for EUF-N were obtained after the different treatments.

Table 2. Contents of some elements in peats and sludge (mg $100 \mathrm{~g}^{-1}$ dry matter)

\begin{tabular}{lcrrrrr}
\hline Sample & N & Na & K & Ca & Mg & P \\
\hline LL & 1500 & 57 & 8 & 74 & 89 & 36 \\
H & 1200 & 103 & 8 & 22 & 31 & 35 \\
T & 1400 & 2530 & 240 & 4914 & 356 & 15 \\
Sludge & 2130 & 1350 & 490 & 3540 & 890 & 1090 \\
\hline
\end{tabular}

For explanation of peat symbols, see Table 1
Table 3. Coefficient of total mineralization for three types of peat and four treatments

\begin{tabular}{lll}
\hline Sample & Treatment & Coefficient \\
\hline LL & Control & 0.51 \\
LL & Sewage sludge & 0.46 \\
LL & Lime & 0.75 \\
LL & Sludge + lime & 1.13 \\
H & Control & 1.87 \\
H & Sewage sludge & 1.54 \\
H & Lime & 2.61 \\
H & Sludge +lime & 2.69 \\
T & Control & 0.60 \\
T & Sewage sludge & 1.18 \\
\hline
\end{tabular}

For explanation of peat symbols, see Table 1. All treatments include incubation for 35 days

Liming caused a drop in the EUF-NH ${ }_{4}^{+}$fraction despite the increase observed in the coefficient of mineralization (Table 3), probably as a result of $\mathrm{N}$ losses by volatilization during incubation. An increase in the organic $\mathrm{N}$ fraction from the inavailable $\mathrm{N}$, occurs after liming.

Adding sewage sludge produced similar effects to liming, and the greatest transformations took place when sludge was applied to the limed sample. In the lime + sludge treatment, both the peat and the sludge microorganisms were more active and, consequently, mineralized the peat much faster than in the other treatments (coefficient of mineralization 1.13). While liming or sewage sludge reduced the $\mathrm{NH}_{4}^{+}$fraction, concurrent addition increased this fraction and, consequently, the level of available $\mathrm{N}$.

Liming clearly accelerated mineralization when applied to the Llano de Ronanzas peat. If this peat is incubated after liming and before being applied to the soil, heavy losses of $\mathrm{N}$ may occur through volatilization or immobilization.

The Herbosa peat (Tables 1,2) is different from the Llano de Roñanzas peat; although the $\mathrm{pH}$ is similar at 3.6 , total $\mathrm{N}$ levels are lower $\left(1200 \mathrm{mg} 100 \mathrm{~g}^{-1}\right)$, the $\mathrm{C}: \mathrm{N}$ ratio is higher (37.5) and the cellulose content is higher $(32 \%)$. This peat is typically brown, with a low grade of decomposition and, consequently, a high mineralization capacity, as shown by the much higher total mineralization coefficients than those of the Llano de Ronanzas peat (Table 3). The incubation of this peat without any other material (control) caused a marked increase in the EUF-N fraction (Fig. 2), with $\mathrm{NH}_{4}^{+}$as the main component, probably as a consequence of the low $\mathrm{pH}$. When sewage sludge was added to this peat and the mixture was incubated, an increase in the EUF-N fraction was obtained (Fig. 2), due to greater formation of $\mathrm{NH}_{3}$. The rate of $\mathrm{N}$ mineralization was probably increased compared with the other two peats because this peat had highest lignin and cellulose contents (Table 2), and there may have been a decrease in the $\mathrm{C}: \mathrm{N}$ ratio. The $\mathrm{NO}_{3}$ contents were so low as to be negligible (Fig. 2).

In contrast to sewage sludge, the addition of lime to the Herbosa peat clearly decreased the EUF-N and EUF$\mathrm{NH}_{4}^{+}$fractions with incubation, and this effect was even 

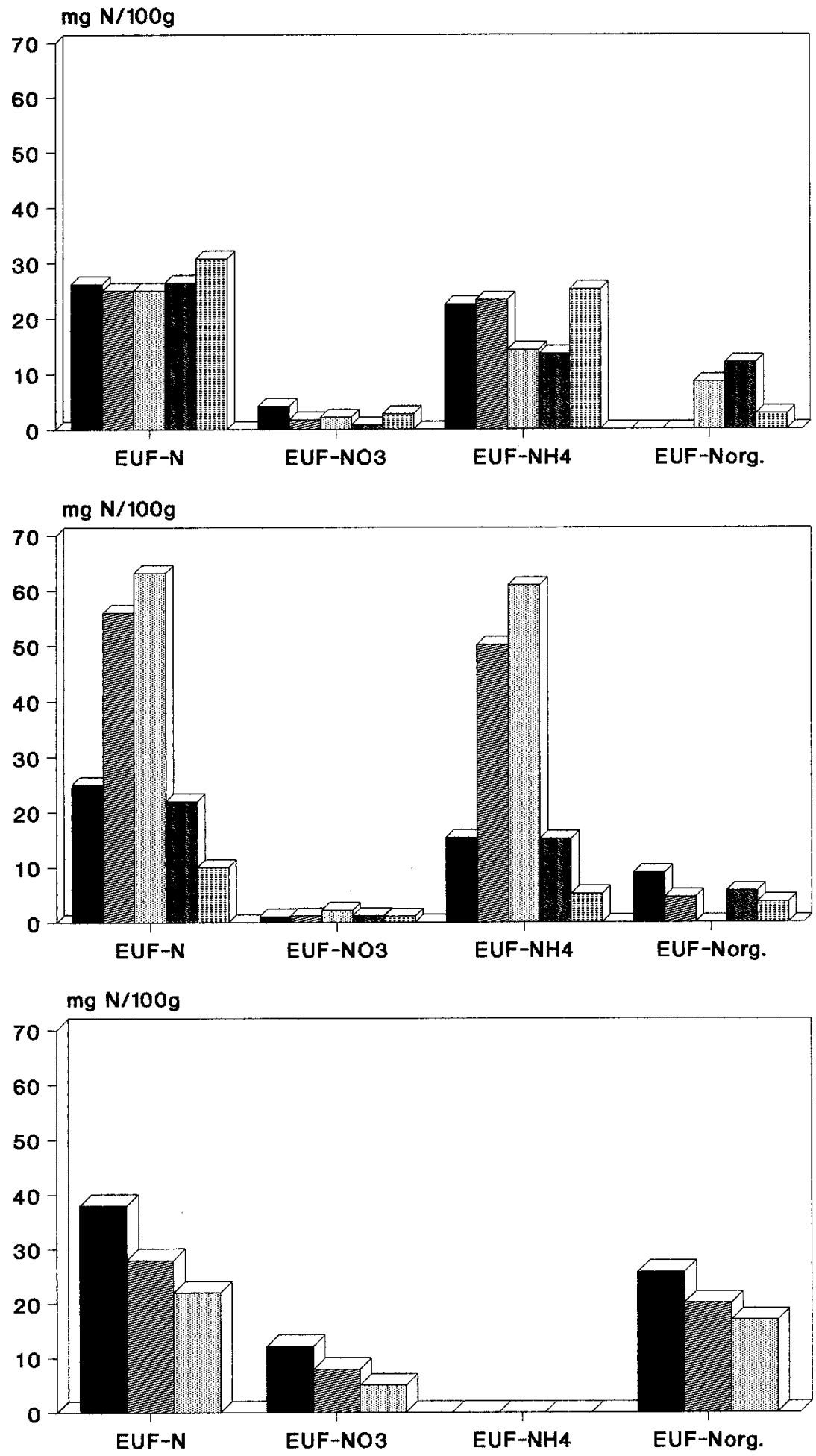

Fig. 1. N mineralization as determined by electroultrafiltration $(E U F)$ in Llano de Roñanzas peat without incubation ( $\mathbf{\square}$ ) and with incubation ( plus the addition of sewage sludge (四), lime (田), or sludge +lime (闂)
Fig. 2. $\mathbf{N}$ mineralization in Herbosa peat; for other explanations, see Fig. 1
Fig. 3. $\mathrm{N}$ mineralization in Torreblanca peat; for other explanations, see Fig. 1 more marked when sewage sludge was added. This behaviour can be explained by the fact that $\mathbf{N}$ mineralization is strongly accelerated with liming and, consequently, $\mathrm{N}$ transformations are very rapid so that the $\mathrm{NH}_{4}^{+}$fraction assessed by electro-ultrafiltration was only a small proportion of the $\mathrm{NH}_{4}^{+}$formed during incubation, owing to losses through volatilization. When Llano peat is used as an agricultural fertilizer, we recommend liming at the time of application, and this is even more necessary for Herbosa peat because the mineralization rates under lim- ing are even more rapid. Double treatment of liming + sewage sludge accelerates the process even further.

The results obtained with the Herbosa peat can be generalized for acid peats with a high $\mathrm{C}: \mathrm{N}$ ratio, high cellulose and low ash contents, and with high electrical conductivity; the addition of sewage sludge to these peats improves the production of plant-available $\mathbf{N}$.

The Torreblanca peat is different from the Llano de Roñanzas and Herbosa peats because it is neutral and sa-

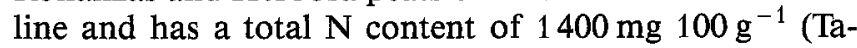


bles 1,2); this peat also has a very high electrical conductivity $\left(10120 \mu \mathrm{S} \mathrm{cm}^{-1}\right)$, reflecting the high $\mathrm{Na}$ and $\mathrm{Ca}$ contents, which probably contribute to the relatively high ash content $(42.9 \%)$. The $C: \mathrm{N}$ ratio is low and the cellulose content medium (Table 1 ). This peat can only be used for agricultural purposes with extreme caution because of its high salt content.

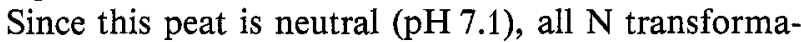
tions were concentrated in the $\mathrm{NO}_{3}^{+}$and organic $\mathrm{N}$ fractions (Fig. 3), unlike the other two peats. Obviously, when studying the effects of incubation on $\mathrm{N}$ availability in this peat, liming treatments were excluded.

Incubation of this peat accelerated $\mathrm{N}$ mineralization and $\mathrm{N}, \mathrm{NO}_{3}^{-}$, and organic $\mathrm{N}$ as assessed by electroultrafiltration fell to low levels, reflecting $\mathrm{NH}_{3}$ losses through volatilization, as observed for the other peats in the liming treatments. Adding sewage sludge accentuated this behaviour, so that these fractions were even lower.

The total mineralization coefficient (Table 3) for this peat when treated with sewage sludge was almost double that of the control sample, probably because the microorganisms added with the urban waste are able to use organic $\mathrm{C}$ which was unavailable to the peat microorganisms.

As a consequence of the results obtained, we classified these peats into two groups according to $\mathrm{pH}$, acid and neutral. Among the acid peats there were two different types, those showing a low mineralization capacity (low $\mathrm{C}: \mathrm{N}$ ratio, low cellulose content and low electrical conductivity) and those with a high mineralization capacity.

The peat with a low mineralization capacity was not substantially affected when incubated alone without any treatment and only slightly by the addition of sewage sludge. In contrast, with the more reactive peat, that from Herbosa, incubation alone and with sewage sludge substantially accelerated mineralization, giving rise to products very rich in available $\mathrm{N}$.

In the two acid peats (Llano de Roñanzas and Herbosa) the addition of sewage sludge reduced the biological activity because this waste depressed the peat microorganisms. Moreover, the sludge microorganisms were unable to act on the peat either, because the peat $\mathrm{pH}$ and biological activity were still too low. The mineralization coefficient decreased in the order Herbosa $>$ Torreblanca $>$ Llano de Roñanzas peat.

Liming favours mineralization of organic matter by increasing the microbial activity, as shown by a greater $\mathrm{CO}_{2}$ release. However, when sewage sludge was added to the limed peats mineralization increased threefold in some cases. With this treatment, a dual effect occurs which increases the biological activity of the medium, both in the peat and the sludge, so that optimum conditions develop. Nevertheless, these effects are relatively low in hemic peats, as observed in the Llano de Roñanzas peat.

In conclusion, a high rate of organic matter mineralization was obtained with liming. This treatment is recommended at the time of peat addition to soil in order to prevent $\mathrm{NH}_{3}$ losses; the greater the peat mineralization capacity, the higher the $\mathrm{NH}_{3}$ losses.
In acid peats, incubation with sewage sludge is recommended to obtain a product richer in available N, but liming is required at the time of application to the soil.

Saline peats like those from Torreblanca have serious limitations for use as fertilizers in view of their high salt content. To avoid this problem, the peat can first be washed with fresh water or be treated with gypsum to replace part of the Na by Ca (Diez et al. 1990). For a better use of $\mathrm{N}$, they should be applied directly to the soil without incubation. Our results also show that the addition of sewage sludge accelerates mineralization.

\section{References}

Boelter DH (1969) Physical properties of peats as related to degree of decomposition. Soil Sci Soc Am Proc 33:606-609

Bunt AC (1974) Some physical and chemical characteristics of loamless pot-plant substrates and their relation to plant growth. Acta Hort 37:1954-1965

Dabin B (1967) Application des dosages automatiques à l'analyse des sols. Cahiers ORSTOM, Sér Péd, vol V, no 3

Diaz-Burgos MA, Polo A (1991) Variaciones de la fracción húmica durante el compostaje de lodos residuales. An Edafol Agrobiol $1: 453-466$

Diez JA (1988) Revisión del métodos de determinacion automatizada de Nitrógenos U. V. oxidable en extractos de suelos. An Edafol Agrobiol 47:1029-1039

Diez JA, Guerrero F, Polo A (1990) Valoración de la capacidad nutriente de diferentes turbas españolas. Agrochimica 34:251-261

Dyal PH (1960) Physical and chemical properties of some peats used as soil amendments. Soil Sci Soc Am Proc 24:268-271

Gallagher P (1975) Peat in protected cropping. In: Robinson DW, Lamb JG (eds) Peat in horticulture. Academic Press, London, pp 170

Guerrero F, Diaz MA, Polo A (1987) Efeito da aplicaçao conjunta de turfas e lodos de esgoto sobre as propiedades quimics de un solo arenoso. In: X Encontro da Sociedade Portuguesa de Química, Porto, Portugal

Guerrero F, Polo A (1988 a) Condiciones de formación y características del histosol de Herbosa (Burgos). Ecología 2:69-78

Guerrero F, Polo A (1988b) Histosoles de la Sierra Plana de Asturias. An Edafol Agrobiol 47:73-86

Lamb JGB (1969) Suitability of peats for the production of nursery stock. In: Peat as medium for horticultural crop production. Am Foras Talumtais, Dublin

Mehlich A (1948) Determination of cation and anion exchange properties of soils. Soil Sci $65: 429-445$

Nemeth K (1979) The availability of nutrients in the soil as determined by electroultrafiltration (EUF). Adv Agron 31:155-158

Nemeth K, Makdum J, Koch K, Beringer H (1979) Determination of categories of soil nitrogen by electroultrafiltration (EUF). Plant and Soil 53:445-453

Nemeth K (1988) Wissenschaftliche Grundlagen der EUF-Stickstoffempfehlung zu Getreide und Hackfrüchten. Int EUF Symposium, Mannheim, Germany, 11-46

Polo A, Almendros G, Dorado E (1983) Dispositivo de incubaciaón para el estudio de la mineralización de la materia orgánica del suelo. An Edafol Agrobiol 42:1335-1340

Puustjarvi V (1974) Physical properties of peat used in horticulture. Acta Hort 37:1922-1929

Puustjarvi V, Robertson (1975) Physical and chemical properties of peats. In: Robinson DW, Lamb JG (eds) Peat in horticulture. Academic Press, London, pp 170

Technicon (1966) Método industrial de determinación de nitrato 5-D. Technicon (EEUU)

Van Soest PJ, Malcolm RM (1968) Determination of lignin and cellulose in acid detergent fiber with permanganate. J AOAC 51:780-785

Wiklickey L, Nemeth K (1991) Düngungsoptimierung mittels EUF-Bodenuntersuchung bei Zuckerrüben. Sonderdruck aus Band 982:988 